\title{
BATHYMETRIC MEASUREMENTS OF A RETENTION RESERVOIR USING INTEGRATED HYDROGRAPHIC AND PHOTOGRAMMETRIC TECHNIQUES
}

\author{
Błażej Mach*, Michał Skrzypek \\ Faculty of Navigation, Gdynia Maritime University, Gdynia, Poland \\ *E-mail of corresponding author: Mach_b@interia.pl
}

\begin{abstract}
Resume
The purpose of this paper was to determine the usability of unmanned hydrographic drones and photogrammetric techniques during the conduct of work, the results of which are potentially to serve as navigational materials in areas that, due to their characteristics, make it impossible to carry out research using crew vessels and direct shoreline determination. In order to prepare and carry out the measurement campaign with the greatest possible accuracy and safety, the authors of the article decided to determine the shoreline of the analyzed reservoir using photogrammetric methods. The use of satellite images allowed the border between land and water to be identified as precisely as possible, which had a direct impact on the accuracy of relating depth data to their location on Earth's globe. Use of unmanned vessels and orthophotos can find practical application when navigating vessels during maneuvers required high precision.
\end{abstract}

Available online: https://doi.org/10.26552/com.C.2022.1.E19-E27

\section{Article info}

Received 9 May 2021

Accepted 4 June 2021

Online 14 October 2021

\section{Keywords:}

Unmanned Surface Vehicle (USV), hydrographic survey, Landsat satellite imagery, photogrammetric survey

ISSN 1335-4205 (print version)

ISSN 2585-7878 (online version)

\section{Introduction}

A significant threat to maritime and inland waterway transport is the phenomenon of ships running aground [1-2]. The depth of even small water surfaces can change dynamically over several meters toward shore. Therefore, in order to safely maneuver a vessel on a water reservoir, it is important to know the shape of its bottom [3-4]. Depth information is obtained by taking hydrographic measurements. Their results allow ship captains to plan and execute the course of mooring maneuvers in the most optimal way. In addition to high accuracy, the actuality of the research is also important. Inland reservoirs, as well as small harbor facilities, are characterized by relatively high changeability, so it is required to update hydrographic studies with adequate frequency [5-6].

Manned hydrographic units are used in areas that are deeper than 1 meter. Unfortunately, in cases where the depth falls below the indicated value, the technical specifications of the vessels make it impossible to conduct the surveys effectively and safely. Therefore, there is a need to improve hydrographic survey methods to obtain accurate bathymetric surveys, in areas with high variability and low depth values. To fully cover the bottom of ultra-shallow water bodies, unmanned craft, both floating [7-11] and flying, are increasingly being used [12-16]. The construction and size of such drones allow surveys to be conducted in areas inaccessible to manned vessels. Additionally, the technical characteristics of such hydrographic devices also allow for quick launching and therefore allow for easy, relatively fast and frequent update work.

Hydrographic surveys should not only provide adequate accuracy in measuring the depth of the body of water being surveyed, but also maintain the required positioning accuracy. For that reason, depth sounders, such as single beam echo-sounders (SBES) and multibeam echo-sounders (MBES), are commonly used when conducting bathymetric surveys of marine and inland areas [17-20]. In addition, Global Navigation Satellite System (GNSS) receivers based on Differential Global Positioning System (DGPS) or Real Time Kinematic (RTK) solutions are used to determine position coordinates [21-25].

Bathymetric maps of ultra-shallow water areas, created by unmanned craft, answer the growing accuracy requirements of the International Hydrographic Organization. Such hydrographic studies also serve to supplement surveys made using the manned craft in areas that are difficult to reach, as well as operators making direct [26]. The accuracy requirements for both depth measurements and positioning are described in document S-44 issued by the International Hydrographic Organization [27].

Despite their small size and high mobility, drones have limitations that apply to all the watercraft. The fact is that the technical characteristics of this type of 


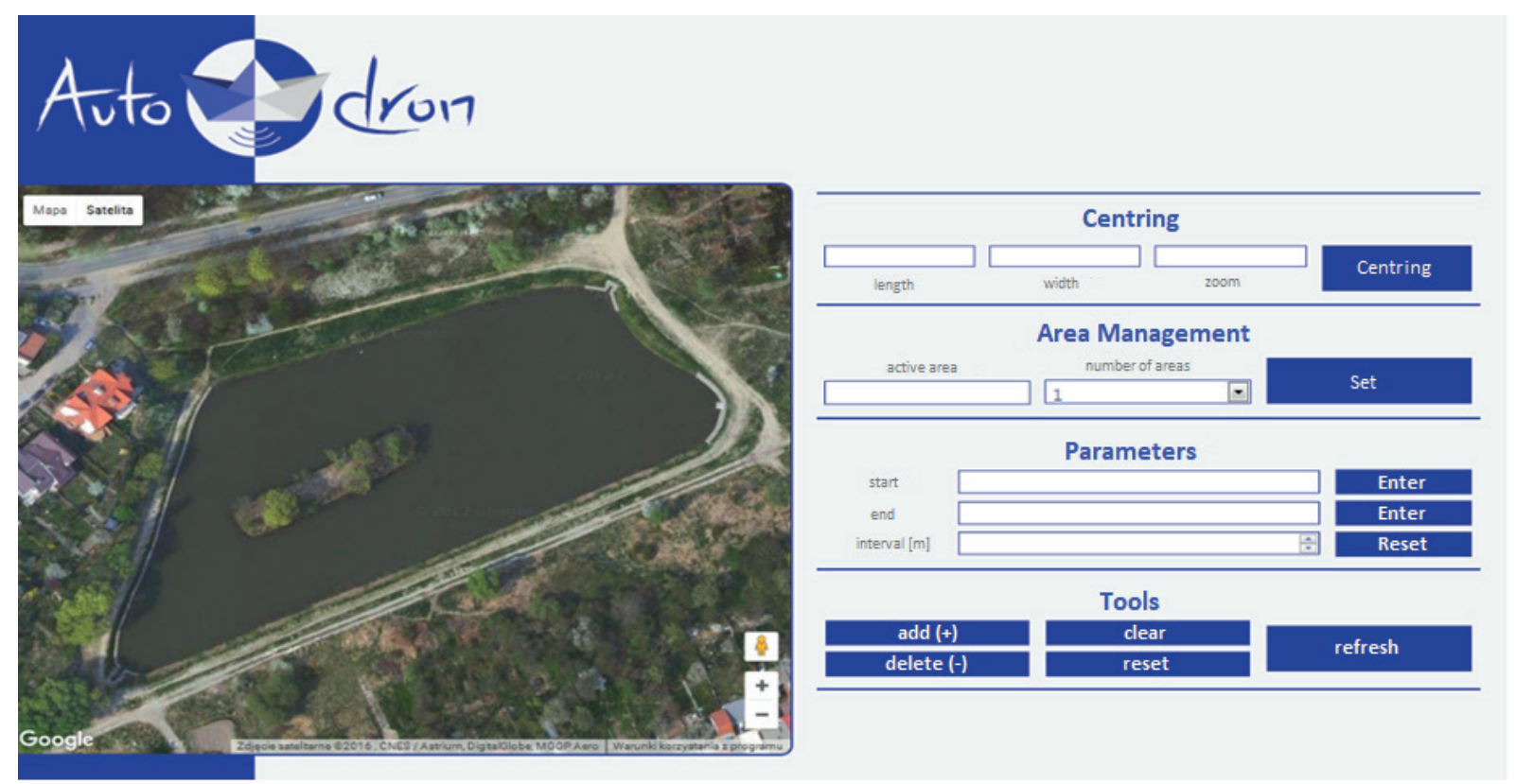

Figure 1 Examples of sounding lines during the bathymetric measurements [30]

equipment make it possible to perform measurements in places that are inaccessible for operators performing direct surveys, as well as for the manned units. Even so, it is impossible to fully cover the entire surface of the water surface where measurements are planned. Additional problems are measurement errors and vehicle deviations from the planned course. These cause that the obtained map of water reservoir is different from the actual state. In order to increase the accuracy of conducted campaigns, orthophotomaps can be used, thanks to which it is possible to obtain an image of the entire surface of the examined reservoir. Such a solution, thanks to relating objects presented on the photomap to localization coordinates, allows to determine the course of the coastline exactly on the land-water border. Another significant benefit of the photogrammetric methods is that they depict all or a significant area of the study area [28]. Consequently, it is possible not only to determine the coastline, but to find out if there are any other objects or surface elements on the surface of the reservoir, as well, that may affect the research being conducted. In addition, it is worth noting that orthophotos are easily available and provide relatively high accuracy. With the use of studies available through free programs, it is possible to determine the position of the indicated point with an accuracy of several $\mathrm{m}$. These advantages make photogrammetric images extremely useful and helpful materials during the preparation and realization of survey campaigns, even though they are not directly used in depth measurements. Despite the many advantages of using the satellite imagery in coastline determination, attention must be paid to its actuality. Due to possible changes that may occur in and around the reservoir, before designing the survey lines based on orthophotomaps, it is necessary to ensure that the images represent the actual status of the reservoir.
Due to water movement, the shape of the coastline may be deformed and movable features such as floating platforms may change their position [29]. Such changes can affect the accuracy of results and if the differences were significant, designing survey profiles based on outdated data can even lead to a damage to the unit.

Due to the above, the aim of this paper was to present the results of bathymetric measurements of the Wilenska reservoir in Gdansk using the integrated hydrographic and photogrammetric methods. The results of the work can be used in carrying out measurements in similar areas, characterized by shallow depths and places inaccessible to other vessels and operators, as well as for the development of hydrographic studies. The use of hydrographic drones is especially useful when surveying such areas as marinas, harbor approach lanes, near-shore areas, small inland reservoirs, and the immediate surrounding of moored vessels, hydrotechnical structures-such as caps and piers.

\section{Materials and methods}

\subsection{Methodology of conducting bathymetric measurements using an USV}

Preparing the vessel for the survey was based on defining the survey profiles along which the device was to move. Motion trajectories can take many forms. Depending on the need, trajectories can be used: parallel or spirals. A unit moving according to the parallel profiles measures from shore to shore, while the spiral lines resemble tapering squares. Figure 1 shows examples of survey lines [30].

The survey profiles presented above are for illustrative purposes only, therefore they may be freely modified, depending on the needs of the conducted 
measurements. Another aspect, regarding the use of unmanned vessel for bathymetric surveys, is the need to consider the weather conditions in the area where the surveys are to take place. Due to the small size of a device there is a risk that its trajectory may be modified by waves or wind. Due to that, measurements should be made at the lowest possible values of the Douglas and Beaufort scales [30]. Other factors that may influence the measurement result are: the speed of sound propagation in water (fluctuation may be daily or seasonal) and the current water level [30]. After taking into account the above mentioned factors, as well as determining the water conditions, it is necessary to carry out a calibration of the equipment used, which can be divided into activities related to preparation of the echo sounder and the GNSS receiver [31]:

Preparing the echo sounder to take measurements involves the following steps:

- calibration (taring) of the vertical echo sounder

- measuring the speed of sound propagation in water;

- measuring the depth at which the sonar transducer is located;

Preparing a satellite receiver requires:

- inclinometer calibration;

- magnetometer calibration.

A manned base unit should also be used during the hydrographic surveys. Besides taking measurements in open areas, it also acts as a safety backup for the unmanned vehicle. When conducting measurements in a small water area, it is enough for the operator to monitor the drone from the shore position [31].

\subsection{Bathymetric measurements \\ of the retention reservoir bottom shape using the hydrographic method}

The device used to perform the measurements described in this article was a HyDrone catamaran made by Seafloor System Inc. The basic element of the drone's construction are two floats made of the highdensity polyethylene (HDPE), which is resistant to environmental conditions and mechanical factors [32]. The floats are connected by an $\mathrm{H}$-shaped frame made of aluminum. The unit has the following dimensions: length $1.1 \mathrm{~m}$, width $0.7 \mathrm{~m}$, draft about $100 \mathrm{~mm}$. The mass of the unit is approximately $25 \mathrm{~kg}$.

A SonarMite v2.1 vertical echo-sounder was used for the measurements. The sonar operated at $200 \mathrm{kHz}$ and the minimum depth that could be measured was $300 \mathrm{~mm}$. When it is necessary to take measurements in shallower areas, it is recommended to use the direct method. Measurement uncertainty during sonar operation was $10 \mathrm{~mm} \pm 0.5 \%$ of the depth. The Trimble R10 GNSS receiver and the Trimble TSC3 controller were used to determine the position of the entire set. The satellite receiver provided reception of all GNSS global navigation satellite systems, so the positioning accuracy reached $10-20 \mathrm{~mm}$. Another advantage, resulting from the use of GNSS systems, was the ability to use an average of $16-20$ satellites in the real time for receiving location data. The echo-sounder and satellite receiver were configured with a controller before the measurements were made. The transducer was connected to the echo sounder using a waterproof cable with IP67 protection class. The receiver and echo sounder with the controller were connected to each other via a Bluetooth system. In addition to manual control, 3DR's PiXHawk autopilot was used during research. To make the autonomous system usable, modifications had to be made. Before the rebuild, each float operated independently, which made it impossible to use an autonomous system [32]. The accuracy parameters given above fulfill the International Hydrographic Organization (IHO) standards as described in document $\mathrm{S}-44$. When measurements were conducted, $1500 \mathrm{~m} / \mathrm{s}$ was taken as the speed of sound in water. This value was not determined experimentally because the maximum depth of the studied water area was $1.5 \mathrm{~m}$, so the measurement error was a few $\mathrm{m}$. Carrying out the survey work took about 2 hours. Due to the minimal operating range of the echo sounder, the smallest measured depth value was $200 \mathrm{~mm}$. To enable the collection of location data it was necessary to connect with the reference station in Gdansk. For this purpose, a commercial real-time RTK service was used, provided by VRSNet.pl company. The connection was made using the General Packet Radio Service (GPRS) cell phone network, and the data from the measurements were recorded on a memory card installed in the receiver in a file with the extension job.

\subsection{Determination of the shoreline of a retention reservoir using the photogrammetric method}

In order to carry out the measurements that were the objective of this research, the coastline of the retention reservoir at Wilenska Street in Gdansk Morena was measured. Due to the characteristics of the study area, photogrammetric images taken by a satellite were used to determine the shoreline. It was done by using the free computer program Google Earth Pro. Using the tool: Add Marked Sites; the border of surveyed water area was determined. This activity consisted of manually marking the contour of the water reservoir using points marks. These points had to be made with appropriate density and taking into consideration where the shoreline was more diverse. A satellite image, taken on $30 / 05 / 2018$, was used to determine the shoreline. This image was taken by the Landsat 8 satellite, which is used by Google Earth when capturing satellite images. The use of Landsat 8 satellite enables the collection of images with a resolution of $15 \mathrm{~m}$ per pixel [33]. Data about the reservoir was exported from Google Earth Pro and entered into the Trimble Business Center software, 


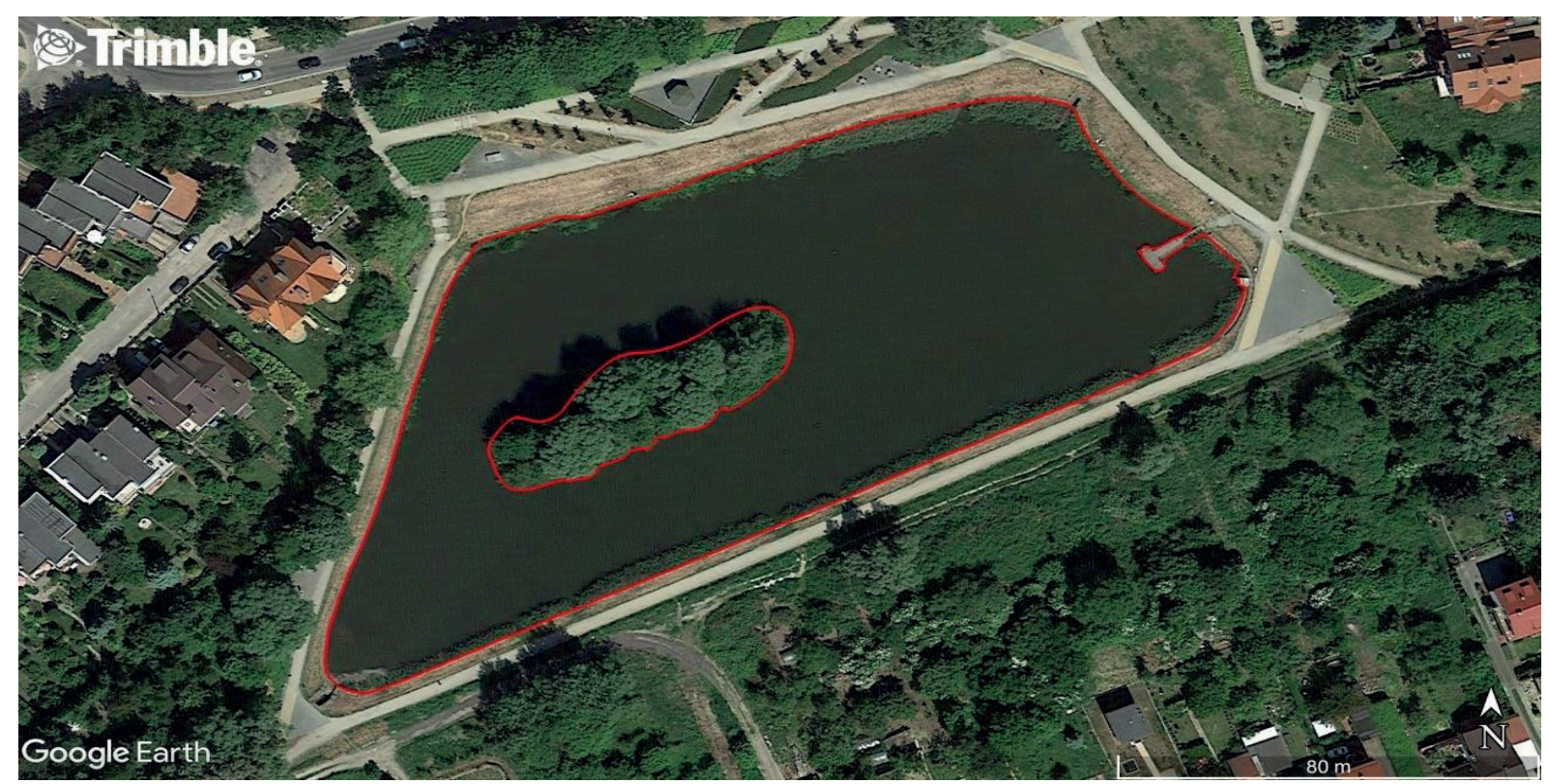

Figure 2 Mapped shoreline using the "Google Earth Pro" software

Table 1 Data processing parameters during reservoir shoreline measurements [32]

\begin{tabular}{ll}
\hline Parameter & Data \\
\hline Country & Poland \\
System/zone & $2000 / 18$ \\
Reference ellipsoid & WGS 84 \\
Ellipsoid semi-major axis & $6378137[\mathrm{~m}]$ \\
Ellipsoid flattening & 0.00335281067183 \\
Projection & Gauss-Kruger \\
Latitude of origin & 0 \\
Central meridian & 18 \\
False Northing & 0 \\
False Easting & 6500 000 \\
Scale factor & 0.999923 \\
Azimuth & North \\
Grid orientation & Rising northeast \\
Transformation of elevation & Geoid \\
Geoid model & PL-geoid-2011 \\
Reference system & Kronstad \\
\hline
\end{tabular}

providing the reservoir shoreline. The result of the work is shown in Figure 2.

\section{Results}

In order to process the data, a measurement campaign was used that was carried out on 03.09.2016 Its aim was to create a numerical model of the bottom on the TIN triangular grid and a bathymetric map of the studied reservoir [32]. The campaign consisted of 2222 measurement points, which were acquired by an unmanned unit operating in both manual and automatic mode. In order to process the measurement points Trimble Business Center software was used, where the processing of the obtained data took place, according to the parameters shown in Table 1.

Using the above parameters, World Geodetic System 1984 (WGS-84) ellipsoidal coordinates were transformed to plane coordinates in the PL-2000 system. Based on the available material, a bathymetric map was created and exported to .kmz format. This extension is supported by the Google Earth Pro, which was used because of its universality, intuitive interface and simplicity of data representation. The result of the study is shown in Figure 3.

The measurements made it possible to determine the size of the reservoir, as well as to create a bathymetric map and a model with isobaths. As per the results, the reservoir has a size of 1.19 ha, its maximum depth 


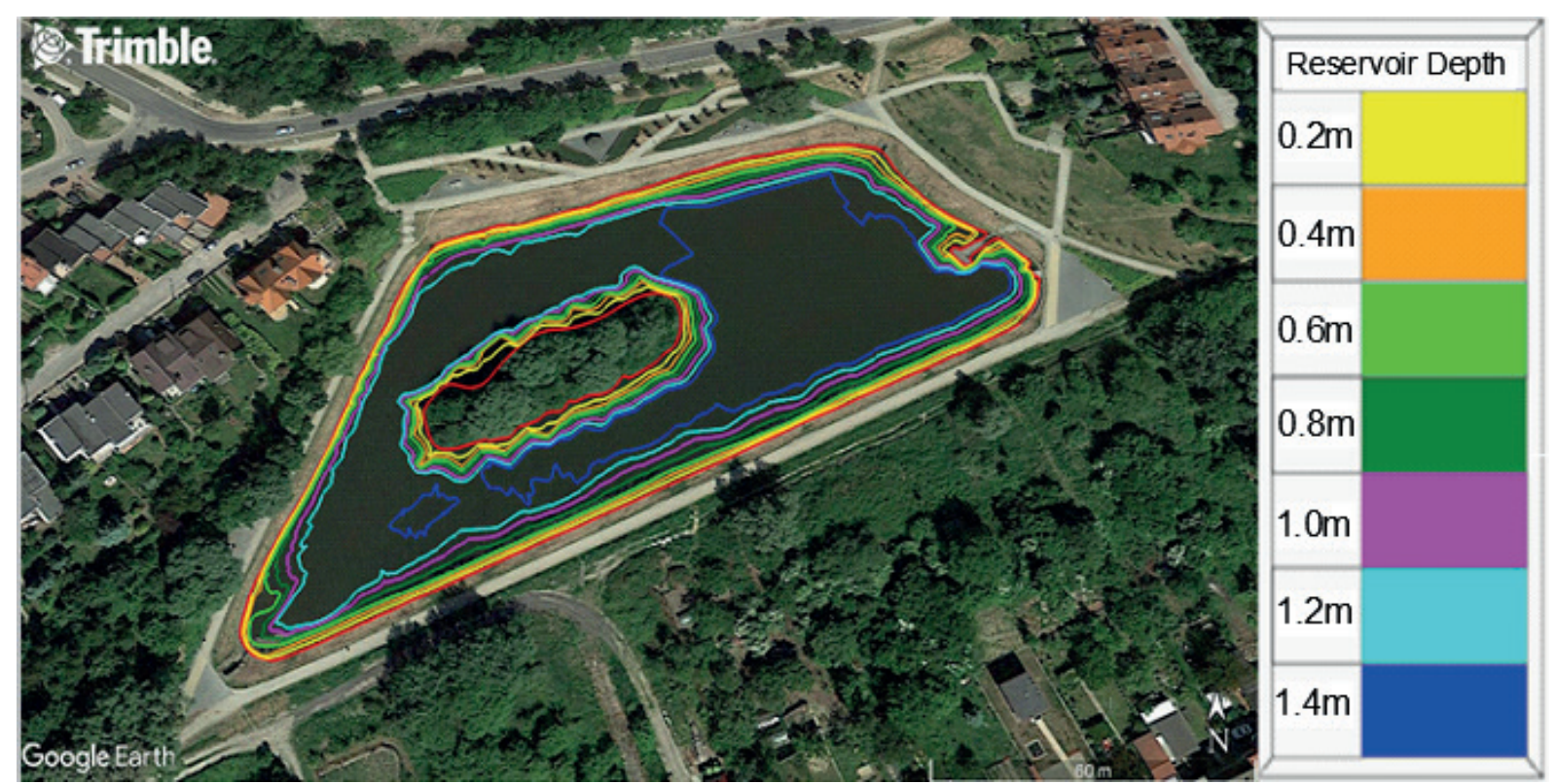

Figure 3 Isobaths applied to satellite image in Google Earth Pro with depth interpretation

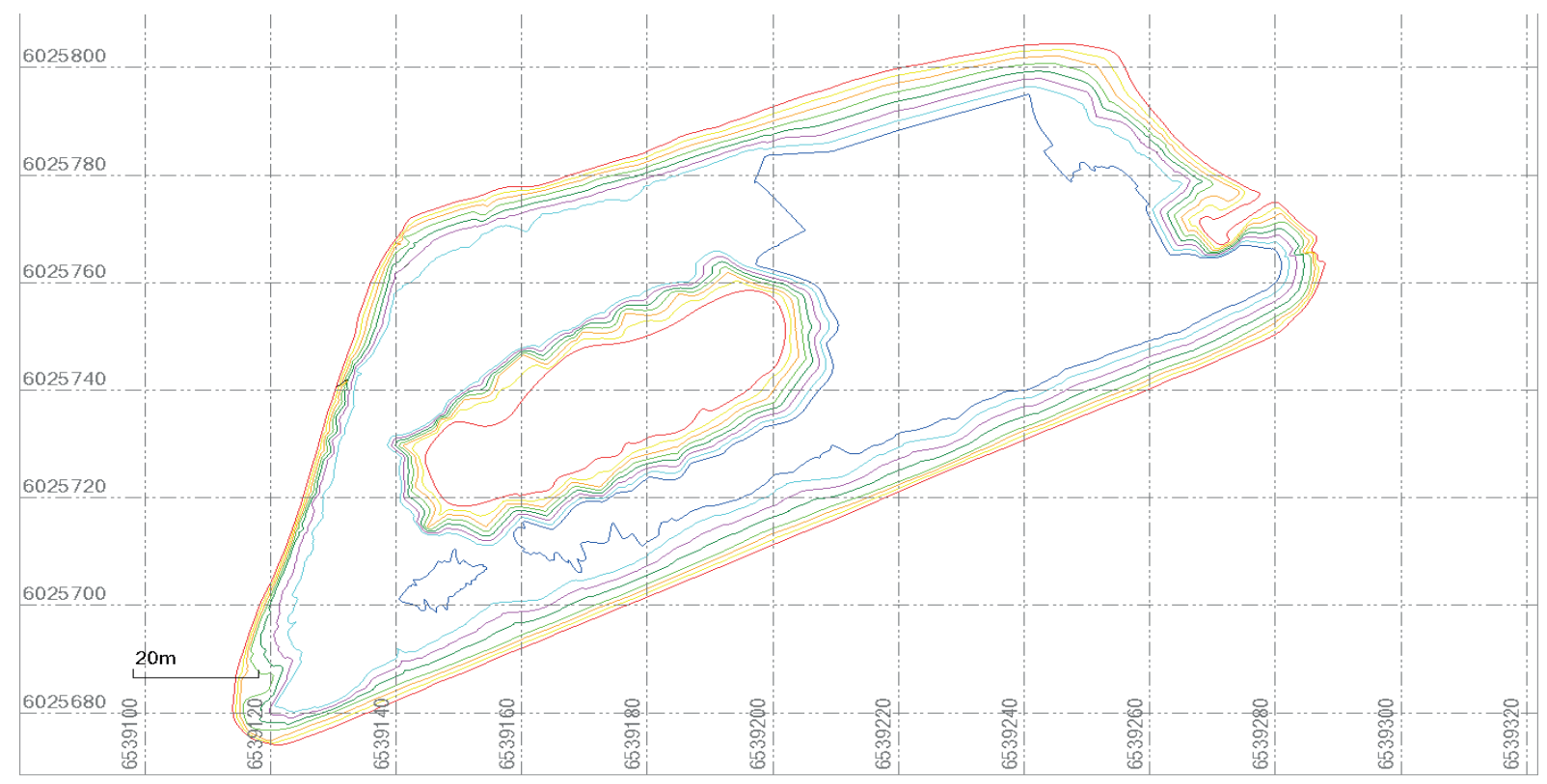

Figure 4 Bathymetric (contour) map of the retention reservoir at Wilenska Street, in the 2000 layout

reaches $1.57 \mathrm{~m}$ and its length is $525 \mathrm{~m}$. A characteristic feature of the investigated artificial reservoir is its steepness, which causes that in the distance of $4-8 \mathrm{~m}$ from the shore a suddenly increased depth to the value of $1.4 \mathrm{~m}$ can be observed. Upon reaching this value, the tank bottom assumes a flat characteristic. In the area of the bottom flattens, the depth of the water body oscillates between 1.4 and $1.57 \mathrm{~m}$, this range represents $50.29 \%$ of the surveyed area. This specification of the reservoir bottom regarding its steepness is an example of how important it is to conduct the bathymetric measurements in shallow water areas. Due to the significant change in depth, maneuvering vessels in such waters may be associated with a risk of damage. Figure 4. shows the map with the isobaths applied.

\section{Discussion}

Due to the low level of seaworthiness of the vessel used during the survey campaign, special attention should be paid during the planning of bathymetric surveys. Because of the technical limitations of the vessel used, the tests should be carried out in the as windless weather as possible and with the lowest waves of water. Therefore, the date of the survey cannot be chosen randomly, but has to consider weather forecasts and there is still a risk that the survey work will have to be postponed or cancelled. Another important aspect of planning and execution of the surveys is to ensure that the satellite images used for the sounding profiles are as up-to-date as possible and correspond with the actual 
condition of the water surface. Attention should be paid to the shape of the shoreline, as well as the presence of various elements on and below the water surface, such as piers, ships and underwater elements of the quay structure. In the case of using outdated photos, there is a risk that due to the planning of the survey trajectory on their base, the unit may be damaged by terrain obstacles and in the worst case - completely broken. This is especially important in areas such as harbors and marinas where there are many moving parts, such as floating piers. The solution to this problem is to go to the place of measurement and directly verify the validity of available satellite images. In addition, the autopilot that was planned to be used to guide the vessel during the survey was not designed to operate in water conditions, due to which rounding of the sounding profiles occurred. In addition, the GPS receiver showed an inaccurate position with an error of several meters. The reason for this problem was the dedicated modem used for the pixhawk autopilot. Despite the difficulties mentioned, the measurements were carried out with acceptable accuracy. It is also worth noting that within 2 hours it was possible to measure an area of 1.17 ha. Therefore, it would take just over 3 hours to survey the entire area of a yacht marina like Puck. During the preparation, implementation and development of measurements, document S-44 was adopted as the document standardizing the methodology and accuracy of surveying [IHO, 2020]. Although this document does not include standards for performing this type of work in inland waters, it is the most widely used and internationally recognized document in the context of bathymetric surveying. Considering that potentially this drone is to be used in areas that are under IHO recommendations, the inclusion of the S-44 standard, in the research presented above will enable future use of the device to make measurements where the specific accuracy will be required. In the context of further development of the described device, it should also be noted that the values obtained above cover depths of less than $1 \mathrm{~m}$. Research work in such shallow waters is significantly complicated by the construction of classical survey vessels. However, due to its low draft, as well as its small size, the unmanned hydrographic drone used for the purpose of this research works well in areas inaccessible to other crafts. The fact that the work was conducted in an area characterized by shallow depths makes the accuracy of the data obtained extremely important. When creating such accurate maps, even small differences between the actual state and the value obtained through measurements can affect the usefulness of such studies, as well as the safety of navigation. Bathymetric studies of ultra-shallow waters can become outdated relatively quickly due to wave motion and movement of the surface layer of the bottom, such as sand. In order to maintain the use value of this type of study, control measurements should be taken relatively frequently.

\section{Conclusions}

The use of such units, as the unmanned hydrographic drone described in this article, significantly contribute to increasing the detail of mapping and other bathymetric studies. Due to the unit's shallow draft, it was possible to collect depth data, with values of less than $1 \mathrm{~m}$, and represent them on the Earth's surface. The acquired data were used to create maps whose depth level is currently unattainable for any institution involved in bathymetric measurements in Poland.

The results obtained during the measurement campaign ranged from 300 to $1570 \mathrm{~mm}$. Such detailed maps significantly reduce navigators' uncertainty when guiding vessels in areas where accurate determination of the water supply under the keel is critical. During the ship mooring in port and other such maneuvering operations, the draft value often closely approximates the depth in a given area. For this reason, from the navigator's perspective, it is necessary that the information about the depth at which he operates is reliable and allows for safe operation of the vessel. Therefore, the use of unmanned hydrographic drones increases safety and reduces the time needed to plan and execute maneuvers in closed waters and activities related to port entry. Despite the fact that the crew of vessels in many cases has a depth sounder on board, the use of a map in which the smallest depth values occurring in a given area are included allows for more efficient, faster and safer planning of the vessel's course.

Usage of unmanned watercraft significantly increases cognitive capabilities when conducting bathymetric work in ultra-shallow waters. As a result of technological development, depth measurements are becoming more and more precise, therefore it is reasonable to increase the accuracy of the other acquired data, having a direct or indirect impact on the final effect of the studies created based on the conducted measurements. Due to increasing opportunities for depth measurements in the immediate nearshore and shallow areas of the reservoir, increasing the precision of the shoreline delineation is complementary to the depth and positioning results obtained. In order to determine the borders of the measured reservoir as precisely as possible, the authors of the paper decided to use orthophotomaps. A significant advantage of this method is the ability to obtain an image of the entire water body, resulting in the ability to quickly determine the border of the entire water area. Current satellite systems used to create this type of study provide a high degree of accuracy in determining the coastline (several tenths of a $\mathrm{mm}$ ). However, the usefulness of photometric systems depends on their actuality. To make their use possible during the planning and realization of measurement campaigns, it is necessary for orthophotomaps to present the actual condition of the reservoir, as well as the equipment and infrastructure located on it. Special attention should be paid to items that may change their position. 
To ensure that the bathymetric studies, created using a hydrographic drone, maintain the required level of map coverage with the actual condition of the water bottom, care must be taken to systematically work on updating the results. This fact causes that the most frequent updating works are recommended, nevertheless that their frequency depends on technical possibilities, needs, and the type of measured reservoir and its bottom, as well. Due to the small size of these units, their easy launch and ability to work in autonomous mode, measurement campaigns can be carried out in a relatively short time. The use of autonomous units is a good supplement to data collected by the conventional manned water vehicles. Therefore, the hydrographic drones provide a solution for measurements in areas inaccessible to conventional vessels, their size, maneuverability and easiness of operation make it possible to measure in shallow and inaccessible areas. In addition, use of the photogrammetric systems allows, when the study area is extended to include the ultra-shallow places, to increase accuracy of the shoreline and other parts of the studied body of water determination.

\section{Acknowledgements}

The work was carried out within the activities of loGIStic Science Club. Supervision during its preparation was exercised by Ph.D. Mariusz Specht.

\section{References}

[1] VANTORRE, M., ELOOT, K., DELEFORTRIE, G., LATAIRE, E. Maneuvering in shallow and confined water. In: Encyclopedia of maritime and offshore engineering [online]. John Wiley \& Sons, 2017. ISBN 9781118476352, eISBN 9781118476406. Available from: https://doi.org/10.1002/9781118476406.emoe006

[2] RUTKOWSKI, G. Determining the best possible speed of the ship in shallow waters estimated based on the adopted model for calculation of the ship's domain depth. Polish Maritime Research. 2020, 27(3), p. 140-148. eISSN 2083-7429. Available from: https://doi.org/10.2478/pomr-2020-0055

[3] SPECHT, M., SPECHT, C., MINDYKOWSKI, J., DABROWSKI, P., MASNICKI, R., MAKAR, A. Modeling of the tombolo phenomenon in Sopot using integrated geodetic and hydrographic measurement methods. Remote Sensing [online]. 2020, 12(4), 737. ISSN 2072-4292. Available from: https://doi.org/10.3390/rs12040737

[4] SPECHT, C., LEWICKA, O., SPECHT, M., DABROWSKI, P. BURDZIAKOWSKI, P. Methodology for carrying out measurements of the tombolo geomorphic landform using unmanned aerial and surface vehicles near Sopot Pier, Poland. Journal of Marine Science and Engineering [online]. 2020, 8(6), 384. ISSN 2077-1312. Available from: https://doi.org/10.3390/jmse8060384

[5] BODUS-OLKOWSKA, I., WAWRZYNIAK, N., ZANIEWICZ, G. Bathymetric surveys for inland electronic navigation charts production of the Lower Odra RIS area / Pomiary batymetryczne na potrzeby produkcji srodladowych elektronicznych map nawigacyjnych obszaru RIS Dolnej Odry (in Polish). Logistyka. 2011, 6, p. 4551-4561. ISSN 1231-5478.

[6] BANDINI, F., OLESEN, D., JAKOBSEN, J., KITTEL, C., WANG, S., GARCIA, M., BAUER-GOTTWEIN, P. Bathymetry observations of inland water bodies using a tethered single-beam sonar controlled by an unmanned aerial vehicle, Lyngby, Denmark: National Space Institute, Technical University of Denmark, 2017.

[7] KUROWSKI, M., THAL, J., DAMERIUS, R., KORTE, H., JEINSCH, T. Automated survey in very shallow water using an unmanned surface vehicle. IFAC PapersOnLine [online]. 2019, 52(21), p. 146-151. ISSN 2405-8963. Available from: https://doi.org/10.1016/j.ifacol.2019.12.298

[8] LI, C., JIANG, J., DUAN, F., LIU, W., WANG, X., BU, L., SUN, Z., YANG, G. Modeling and experimental testing of an unmanned surface vehicle with rudderless double thrusters. Sensors [online]. 2019, 19(9), 2051. eISSN 1424-8220. Available from: https://doi.org/10.3390/s19092051

[9] MU, D., WANG, G., FAN, Y., QIU, B., SUN, X. Adaptive trajectory tracking control for underactuated unmanned surface vehicle subject to unknown dynamics and time-varying disturbances. Applied Sciences [online]. 2018, 8(4), 547. eISSN 2076-3417. Available from: https://doi.org/10.3390/app8040547

[10] WROBEL, K., WEINTRIT, A. With regard to the autonomy in maritime operations - hydrography and shipping, Interlinked. TransNav the International Journal on Marine Navigation and Safety of Sea Transportation [online]. 2020, 14(3), p. 745-749. ISSN 2083-6473. Available from: https://doi.org/10.12716/1001.14.03.29

[11] YANG, Y., LI, Q., ZHANG, J., XIE, Y. Iterative learning-based path and speed profile optimization for an unmanned surface vehicle. Sensors [online]. 2020, 20(2), 439. eISSN 1424-8220. Available from: https://doi.org/10.3390/s20020439

[12] ANGNUURENG, D. B., JAYSON-QUASHIGAH, P.-N., ALMAR, R., STIEGLITZ, T. C., ANTHONY, E. J., AHETO, D. W., ADDO, K. A. Application of shore-based video and unmanned aerial vehicles (drones): complementary tools for beach studies. Remote Sensing [online]. 2020, 12(3), 394. eISSN 2072-4292. Available from: https://doi.org/10.3390/rs12030394 
[13] BURDZIAKOWSKI, P., SPECHT, C., DABROWSKI, P. S., SPECHT, M., LEWICKA, O., MAKAR, A. Using UAV photogrammetry to analyze changes in the coastal zone based on the Sopot Tombolo (Salient) Measurement Project. Sensors [online]. 2020, 20(14), 4000. eISSN 1424-8220. Available from: https://doi.org/10.3390/s20144000

[14] CONTRERAS-DE-VILLAR, F., GARCJA, F. J., MUNOZ-PEREZ, J. J., CONTRERAS-DE-VILLAR, A., RUIZORTIZ, V., LOPEZ, P., GARCIA-LOPEZ, S., JIGENA, B. Beach leveling using a Remotely Piloted Aircraft System (RPAS): problems and solutions. Journal of Marine Science and Engineering [online]. 2021, 9(1), 19. ISSN 2077-1312. Available from: https://doi.org/10.3390/jmse9010019

[15] GENCHI, S. A., VITALE, A. J., PERILLO, G. M. E., SEITZ, C., DELRIEUX, C. A., Mapping topobathymetry in a shallow tidal environment using low-cost technology. Remote Sensing [online]. 2020, 2(9), 1394. eISSN 2072-4292. Available from: https://doi.org/10.3390/rs12091394

[16] LOWE, M. K., ADNAN, F. A. F., HAMYLTON, S. M., CARVALHO, R. C., WOODROFFE, C. D. Assessing reefisland shoreline change using UAV-derived orthomosaics and digital surface models. Drones [online]. 2019, 3(2), 44. eISSN 2504-446X. Available from: https://doi.org/10.3390/drones3020044

[17] JIN, J., ZHANG, J., SHAO, F., LV, Z., LI, M., LIU, L., ZHANG, P. Active and passive underwater acoustic applications using an unmanned surface vehicle. In: OCEANS 2016 MTS/IEEE: proceedings. IEEE, 2016.

[18] SETO, M. L., CRAWFORD, A. Autonomous shallow water bathymetric measurements for environmental assessment and safe navigation using USVs. In: OCEANS 2015 MTS/IEEE: proceedings. IEEE, 2015.

[19] STATECZNY, A., BURDZIAKOWSKI, P. Universal autonomous control and management system for multipurpose unmanned surface vessel. Polish Maritime Research [online]. 2019, 26, p. 30-30. eISSN 2083-7429. Available from: https://doi.org/10.2478/pomr-2019-0004

[20] ZWOLAK, K., WIGLEY, R., BOHAN, A., ZARAYSKAYA, Y., BAZHENOVA, E., DORSHOW, W., SUMIYOSHI, M., SATTIABARUTH, S., ROPEREZ, J., PROCTOR, A., WALLACE, C., SADE, H., KETTER, T., SIMPSON, B., TINMOUTH, N., FALCONER, R., RYZHOV, I., ELSAIED ABOU-MAHMOUD, M. The autonomous underwater vehicle integrated with the unmanned surface vessel mapping the Southern Ionian Sea. The Winning Technology Solution of the Shell Ocean Discovery XPRIZE. Remote Sensing [online]. 2020, 12(8), 1344. eISSN 2072-4292. Available from: https://doi.org/10.3390/rs12081344

[21] SPECHT, C., SPECHT, M., DABROWSKI, P. Comparative analysis of active geodetic networks in Poland. In: 17th International Multidisciplinary Scientific GeoConference SGEM 2017: proceedings [online]. 2017. Vol. 17, Iss. 22. ISBN 978-619-7408-02-7, ISSN 1314-2704, p. 163-176. Available from: https://doi.org/10.5593/sgem2017/22/ $\mathrm{S} 09.021$

[22] DZIEWICKI, M., SPECHT, C. Position accuracy evaluation of the modernized Polish DGPS. Polish Maritime Research [online]. 2009, 16(4), p. 57-61. eISSN 2083-7429. Available from: https://doi.org/10.2478/v10012-0080057-x

[23] ARROYO-SUAREZ, E. N., RILEY, J. L., GLANG, G. F., MABEY, D. L. Evaluating a global differential GPS system for hydrographic surveying, In: OCEANS 2005 MTS/IEEE: proceedings [online]. IEEE, 2006. ISSN 0197-7385, ISBN 0-933957-34-3. Available from: https://doi.org/10.1109/OCEANS.2005.1640155

[24] ERENER, A., GOKALP, E. Mapping the sea bottom using RTK GPS and lead-line in Trabzon harbor. In: FIG Working Week 2004 Workshop: proceedings. 2004.

[25] STATECZNY, A., BURDZIAKOWSKI, P., NAJDECKA, K., DOMAGALSKA-STATECZNA, B. Accuracy of trajectory tracking based on nonlinear guidance logic for hydrographic unmanned surface vessels. Sensors [online]. 2020, 20(3), 832. eISSN 1424-8220. Available from: https://doi.org/10.3390/s20030832

[26] SUHARI, K., KARIM, H., GUNAWAN, P., PURWANTO, H. Small ROV marine boat for bathymetry surveys of shallow waters - potential implementation in Malaysia. The International Archives of the Photogrammetry, Remote Sensing and Spatial Information Sciences [online]. 2017, XLII-4/W5, p. 201-208. eISSN $2194-9034$. Available from: https://doi.org/10.5194/isprs-archives-XLII-4-W5-201-2017

[27] IHO. IHO Standards for hydrographic surveys. 6. ed. IHO Publication No. 44. Monte Carlo, Monaco, 2020.

[28] BODUS- OLKOWSKA, I. Basic hydrography lesson script / Skrypt do zajec z przedmiotu podstawy hydrografii (in Polish). In: Basics of geodesy and hydrography / Zaktad geodezji i hydrografii. Szczecin: Akademia Morska w Szczecinie, Instytut Geoinformatyki, 2018

[29] DUDZIŃSKA- NOWAK, A. Determining the development trends of the shore on the basis of remote sensing research / Okreslenie tendencji rozwojowych brzegu na podstawie badan teledetekcyjnych (in Polish). In: Basics of remote sensing and maritime cartography / Zaktad teledetekcji i kartografii morskiej. Szczecin: Uniwersytetski Instytut Nauk o Morzu, Wydział Nauk o Ziemi, 2008.

[30] SPECHT, M., SPECHT, C., WAZ, M., NAUS, K., GRZADZIEL, A., IWEN, D. Methodology for performing territorial sea baseline measurements in selected waterbodies of Poland. Applied Sciences [online]. 2019, 9(15), 3053. eISSN 2076-3417. Available from: https://doi.org/10.3390/app9153053 
[31] GRZADZIEL, A. Metodyka wykonywania badan hydrograficznych przeszkod podwodnych / Single beam echo sounder in hydrographic surveys (in Polish). Przeglad Morski / Maritime Review. 2006, 7/8, p. 29-45. ISSN 0137-7205.

[32] SPECHT, C., SWITALSKI, E., SPECHT, M. Application of an autonomous/unmanned survey vessel (ASV/ USV) in bathymetric measurements. Polish Maritime Research [online]. 2017, 24(3), p. 36-44. eISSN 2083-7429. Available from:

[33] PIEKARCZYK, J. Satellite, aerial and terrestrial remote sensing / Teledetekcja satelitarna, lotnicza i naziemna (in Polish). In: Basics of cartography and geomatics / Zaktad kartografii $i$ geomatyki. Poznan: Instytut Geografii Fizycznej i Ksztaltowania Srodowiska Przyrodniczego Uniwersytet im. Adama Mickiewicza, 2019 